\title{
Studying the Role of Financial Risk Management on Return on Equity
}

\author{
Saeed Fathi ${ }^{1}$, Fatemeh Zarei $^{1} \&$ Sharif Shekarchizadeh Esfahani ${ }^{2}$ \\ ${ }^{1}$ School of Administrative Sciences and Economics, University of Isfahan, Isfahan, Iran \\ ${ }^{2}$ School of Management, University of Texas at Dallas, Richardson, U.S.A \\ Correspondence: Sharif Shekarchizadeh Esfahani, School of Management, University of Texas at Dallas, 800 \\ West Campbell Rd. Richardson, TX 75080, USA. Tel: 1-972-603-8599. E-mail: sharif_shekarchi@yahoo.com
}

Received: December 2, 2011

Accepted: January 13, 2012 Published: May 1, 2012

doi:10.5539/ijbm.v7n9p215

URL: http://dx.doi.org/10.5539/ijbm.v7n9p215

\begin{abstract}
Nowadays risk has an important role in all countries, and its management is valuable for banks to the extent that they publish their applying methods about risk management and their operations and results in a scheduled order toward customer orientation in order to gain stockholders' confidence. In this article, three instruments of bank risk management are represented by means of financial ratios consisting of interest rate risk, capital risk and risk of natural hedging. So, the basic problem in this paper is the impact of risk management on stockholders' wealth. Stockholders' wealth is measured by Return on Equity (ROE). This article has three hypotheses, the major one of which is that there is a significant correlation between risk indices and ROE. Results show that interest rate risk and diversification risk have significant correlation with ROE, but there is no significant correlation between credit risk and ROE.
\end{abstract}

Keywords: risk management, Return On Equity (ROE), financial ratios, Return On Assets (ROA), Equity Multiplier (EM)

\section{Introduction}

Risk has been defined as a subject that causes actual and direct loss to the organization through decreasing income flow and capital loss. Due to the role of financial markets in the architecture of an economy (Durnbusch et al., 2004), one can say that financial institutions (such as banks, stock exchange intermediaries, mutual funds, etc.) can have an important effect on economy-wide crisis. Economy-wide crisis on macro level increases the cost of socio-economic development and in micro level leads to business management uncertainty and bankruptcy. So, managers and researchers should try to control the effects and consequences of risk in micro and macro levels. Many of the researchers have recommended that risk must be managed but not destroyed (Saunders and Cornett, 2006; Dubofsky, 1992; Das, 2006). Therefore, paying attention to risk management is one of the main policies in each economy (Sander et al., 2006), but it can be different based on differences in business characteristics. With this point of view, we should assess all kinds of risks in an enterprise by different measures and then pay attention to develop suitable risk management instruments to decrease the negative effects of risky events. In an operationalized definition, risk is the possibility of change in the future profits (Neveu, 1986). Future profit has been measured by using different measures such as ROE in the Du Pont equation (Ehrhardt and Brigham, 2011). Due to the role of a business profit on its stockholder's wealth and accordingly its impact on cost of capital, risks have been entered in the list of critical success factors for business (Ogden et al., 2003). Based on the importance of financial institutions in micro and macro level and the critical role of risk management in controlling crisis costs, researchers and practitioners have paid attention to the quality and operationalization of risk management in different business activities (COSO, 2004). This subject, risk, has led to different studies which have emphasized on the effects of financial risk management on future profit of financial institutions and specially banks (Saunders and Cornett, 2006; Ruda, 2009; Leea, 2000; Greuning and Sonja, 1999). As in such studies, we try to define risk as sensitivity of banks stock or ROE to different risk factors in this study. Then, we analyze the effects of financial risk management instruments on Iranian banks ROE. In the second section, we will discuss about the dimensions of risk in banking sector, and our conceptual model will be presented. The third section will be about research methodology, and in the fourth the results are reported. Finally, we discuss about the results and conclusions in the last section. 
Credit risk refers to the risk of loss arising from the default of the counter-party, that is the failure to honor and meet its legal obligations or changes in credit quality that affect the value of financial instruments (Das, 2006). Operating risk is a dimension of risk related to direct or indirect losses that rise from inadequate or incorrect processes inside the organizations, individuals, systems or events outside the organization. Market risk is a kind of risk related to those losses imposed on banks' assets based on changes and fluctuations of market factors such as foreign exchange rate, interest rate, stock price and etc (Jones, 2009). According to Thomas and Bierd's definition, market risk is applying capital assets pricing model in order to measure risk. Liquidity risk is the risk of lack of cash for commitments' repayment (Jones, 2009). Capital risk is the possibility of encountering lack of the necessary capital as the last financial fund and storage.

\section{Literature Review}

Raee(2009) has generally divided risk into two categories of financial risk and nonfinancial risk (Raee, 2009).

Financial risk includes exchange rate risk, interest rate risk, credit risk, liquidity risk, Inflation risk, stock price risk, and reinvestment risk. Also, non-financial risks include managerial risk, political risk, industry risk, operating risk, regulation risk, and human resource risk (Figure 1).

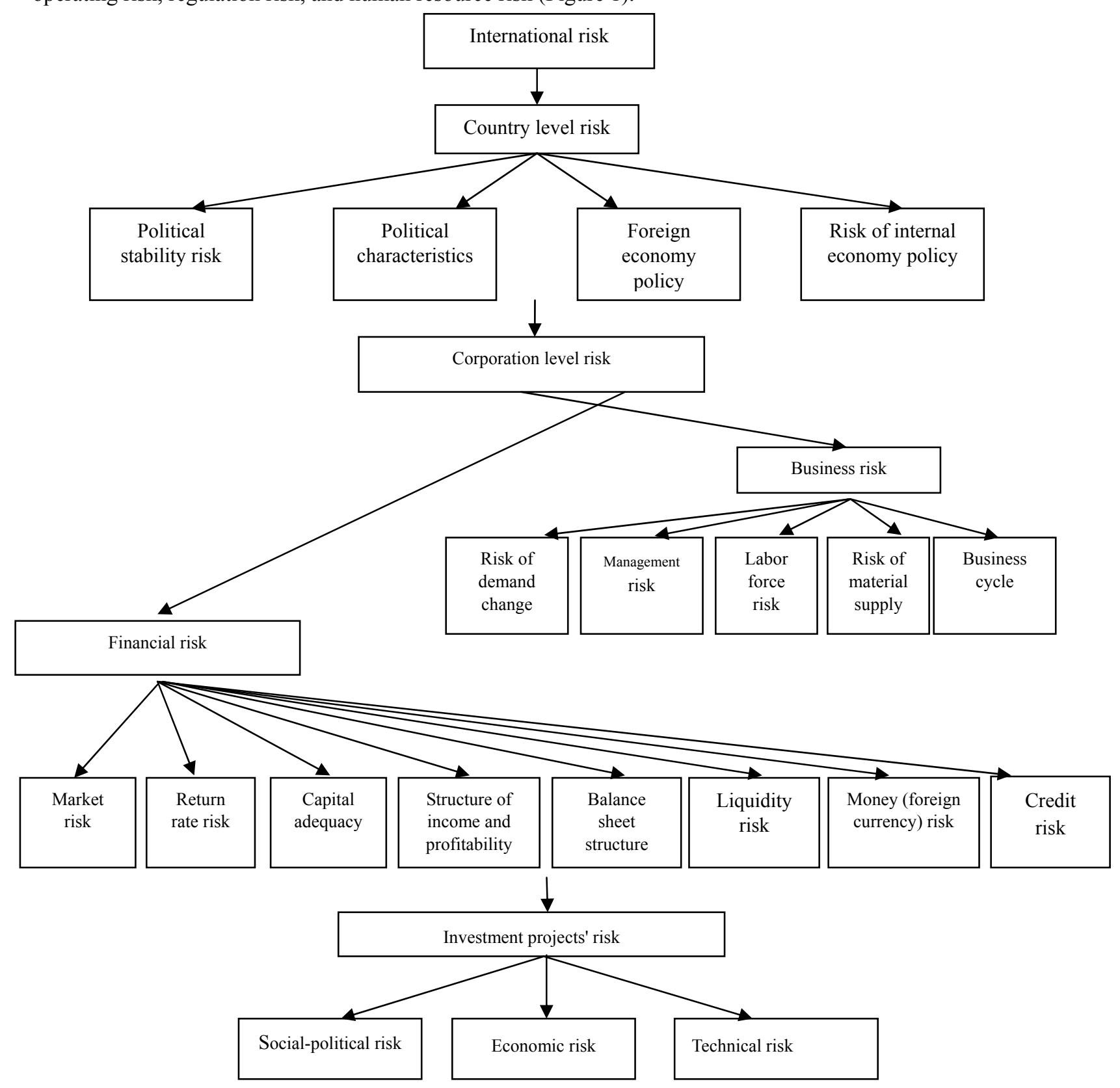

Figure 1. Risk hierarchical categorization model (Fathi 2003) 
Fathi (2003) has categorized the risk at four levels of international, country, company and project with a hierarchical view on various levels of risk (Figure 2) (Fathi and Bagheri, 2003). Also according to Das (1999) different Kinds of risk in the banking system are credit risk, operating risk, market risk, liquidity risk, and capital risk.

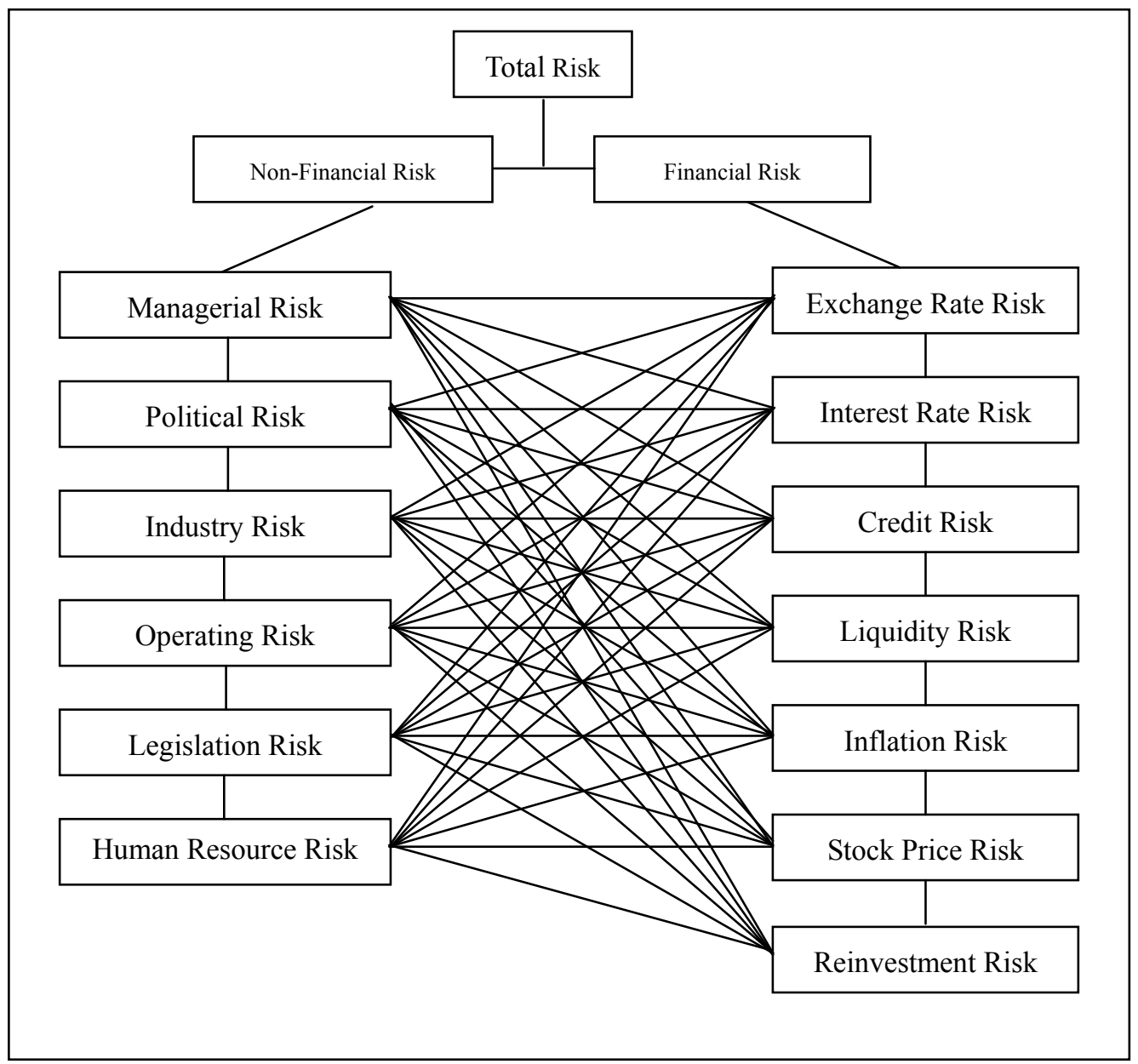

Figure 2. Different kinds of financial and non-financial risk (Raee, 2009)

\section{Conceptual Model}

According to Rudra(2009), a general framework is presented for evaluating commercial banks' performance of risk management with due attention to the basic purposes of companies i.e., increasing stockholders' wealth by the measure of ROE (Rudra, 2009). We will analyze the elements of banks' ROE by means of the Du Pont equation. Based on this, we divide the effectiveness level of ROE of banks into two parts of operational ration (equation 1).

$$
\text { ROE }=\frac{\text { Profit after tax }}{\text { Total assets }} \times \frac{\text { Total assets }}{\text { Equity }}
$$

In this equation, profit after tax to total assets is used to measure ROA, and ratio of total assets to equity is Equity Multiplier. In the next step (equation 2), ROA is disintegrated into the following elements:

$$
R O A=\frac{I I-I E}{T A}+\frac{N I I-N I E}{T A}-\frac{\text { Provisions }}{T A}
$$

II: Interest Income

IE: Interest Expense

NII: Non-Interest Income

NIE: Non-Interest Expense 


\section{TA: Total Assets}

Then, equation (2) could be stated as:

$$
R O A=\text { Net interest margin }+ \text { Non interest margin - Provision to total assets }
$$

Finally, by replacing equation (3) in equation (1) we have:

$$
R O E=(N E T I M+N O N I M-P R O V)^{*}(E M)
$$

Where NETIM is net interest margin, NONIM is non-interest margin, PROV is provision to total assets and EM is equity multiplier. Equation (4) shows that the banks can achieve their purpose to maximize stockholders' wealth through maximizing NETIM, NONIM and EM and minimizing PROV that is ROE with regard to assets. In the following analysis, capability of banks in risk management is evaluated using these four factors.

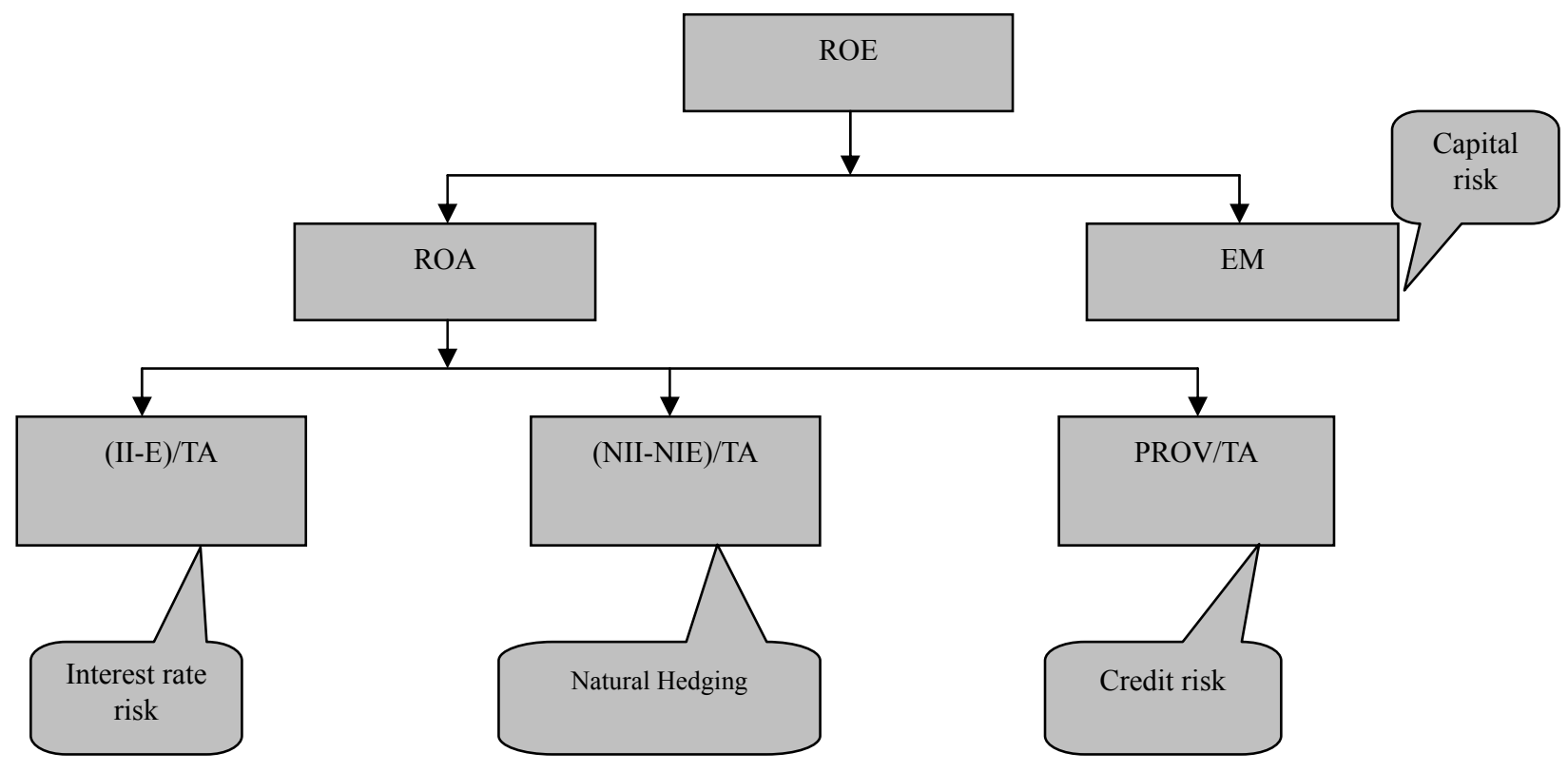

Figure 3. Conceptual Model (Bill et al., 2004)

Interest rate risk in banks leads to reduction of banks' net income because of changing interest rate. The Interest rate affects the Net Interest Margin (NETIM) and changes ROA. This change results from the change in stockholders' wealth. The Net interest margin of bank stockholders is decreased by reduction in the interest rate. Banks use swap and future contracts in order to prevent interest rate reduction. Future contractsare contract on buying or selling assets at a certain time in the future with a specific price which has numerous applications in the stock exchange (Raee, 2009). Swap is selling one kind of security and buying a similar security in order to reduce or increase tax (Raee, 2009).

The Net Interest Margin(NETIM) shows sensitivity and elasticity of banks towards interest rate risk. Income ration as another ratio, other than interest to total assets i.e., NETIM is considered as an index to show banks' capabilities in risk management.

\section{Credit Risk}

Credit introduces the amount of money that will be paid in the future, and credit risk exists because the expected payments may not be paid. Therefore, by credit risk we mean potential losses received by the customer of credit, but repayment has encountered refusal by the customer or there has been no financial capability of complete or timely repayment (Rudra, 2009). Delayed repayments lead to reduction of banks' assets and provision of total assets (PROV) is also decreased. As a result, ROA and ROE will be reduced. Thus, there is a reverse relationship between credit risk and ROE (Rudra, 2009).

\section{Capital Risk}

The ratio of capital to assets shows a bank's capability against sudden losses and supports implicitly the profits of assured depositors. If this ratio is high, it gives rise to establishing depositors' confidence in the bank, but it may reduce ROE. Hence, maximization of ROE depends on the relationship between ROA and the equity multiplier 
(EM). Banks enhance ROE of stockholders by increasing the equity multiplier, but the higher equity multiplier shows that the ratio of capital to assets is low; and consequently, capital risk is high. Therefore, it could lead to closing banks. It is argued that stockholders prefer low capital risk with an open view for sustainability of dividend distribution by the bank (Anderson, 2003). In this study, the ratio of capital to assets has been considered as a criterion to evaluate the capability of banks in capital risk management. In order to measure the amount of capital risk, we use a criterion called the capital adequacy coefficient. This coefficient is the adequate amount of capital to cover capital risk and is put aside as capital stock (Raee, 2009).

Finally, banks can choose various strategies in order to counter with all types of risks and, in this way, increase non-interest incomes despite total income (Bill et al., 2007). Non interest incomes are obtained from different activities, for instance, through services such as money transfer or other payment services, credit cards, contract uses such as future contracts and swap contracts, etc. that enhance ROA without increasing risk (Bill et al., 2004).

It is argued that sustainable increase in non-interest incomes of banks may show that banks have adopted various strategies to improve profitability and ROE. We consider the ratio of non-interest margins to total assets i.e., NONIM as a strategy of the natural encountering index with the bank's risk that is expected to have a positive effect on ROA. Banks may encounter other risks like liquidity risk and operating risk. The framework and basis of the financial index that have been previously selected do not consider such risks. Hence, with regard to credit risk, interest rate risk and capital risk, risk management capabilities in the bank have been analyzed clearly. It is expected that NONIM explains all the strategies of risk management in this study.

Table 1 demonstrates how ROE relates tothe four indices of risk management that have been studied. These indices may often be in opposition with each other. For example, it is possible that in some conditions, a bank has high NETIM but low PROV, while another bank comes to a different conclusion with another method. It is clear in such cases that the first bank has a higher ROE than the second one. But from the risk management viewpoint, it is not obvious that which bank has the better risk management. The first bank may manage its interest rate risk better, while the second one may be superior in terms of credit risk. Such replacements have been experienced in the banking industry for risk management strategies. For instance, Schrand and Unal (1998) have found a negative relationship between interest rate risk and credit risk. It is obvious that such a phenomenon shows the necessity of creating relationship among different indices so that a comprehensive evaluation from capabilities of risk management in banks could occur. The necessity of such relationships is what we intended to achieve before studying concepts of risk management in order to increase stockholders' wealth.

\section{Research Hypotheses}

$\mathrm{H}_{1}$ : There is a significant relationship between interest rate risk and ROE in banks.

$\mathrm{H}_{2}$ : There is a significant relationship between natural hedging risk and ROE in banks.

$\mathrm{H}_{3}$ : There is a significant relationship between capital risk and ROE in banks.

According to these hypotheses, our regression model is as follows:

$$
\mathrm{ROE}=\mathrm{C}_{1}+\mathrm{C}_{2}{ }^{*} \mathrm{CA}+\mathrm{C}_{3}{ }^{*} \mathrm{NH}+\mathrm{C}_{4}{ }^{*} \mathrm{IR}
$$

$\mathrm{CA}=$ CapitalRisk

$\mathrm{NH}=$ Natural Hedging

$\mathrm{IR}=$ Interest Rate Risk

\section{Research Methodology}

This research is a descriptive research in which regression analysis has been used to test the existence of relationships among variables and significance of estimated models. This means that linear and non-linear relationships among financial ratios with stocks return have been examined to study significance level of coefficients of regression models. So, regression models are estimated by using E-views statistical software, and then significance of the regression model is tested through circumstantial evidence oft-test on $95 \%$ of confidence level. The Durbin Watson test has been used to examine auto-correlation of variables.

We obtained the data from the financial statements of the banks listed in the Tehran Stock Exchange (TSE), and data have been collected during the 6-month period from 2009 to 2010. 


\section{Results}

Table 1 shows the results of the model statistics.

Table 1. Results of the Model Statistics

\begin{tabular}{|c|c|c|c|c|}
\hline \multicolumn{5}{|c|}{$\begin{array}{l}\text { Dependent Variable: ROE } \\
\text { Included observations: } 20 \text { after adjustments } \\
\text { ROE }=\mathrm{C}_{1}+\mathrm{C}_{2} * \mathrm{CA}+\mathrm{C}_{3} * \mathrm{NH}+\mathrm{C}_{4} * \mathrm{IR}\end{array}$} \\
\hline & Coefficient & Std. Error & t-Statistic & Prob. \\
\hline $\mathrm{C}_{1}$ & 3.032698 & 1.811155 & 1.674455 & 0.1135 \\
\hline $\mathrm{C}_{2}$ & -0.035067 & 0.039480 & -0.888219 & 0.3876 \\
\hline $\mathrm{C}_{3}$ & 12.76417 & 2.929220 & 4.357532 & 0.0005 \\
\hline $\mathrm{C}_{4}$ & 2.136126 & 0.911143 & 2.344448 & 0.0323 \\
\hline R-squared & 0.563010 & \multicolumn{2}{|c|}{ Mean dependent var } & 0.576996 \\
\hline Adjusted R-squared & 0.481075 & \multicolumn{2}{|c|}{ S.D. dependent var } & 7.567368 \\
\hline S.E. of regression & 5.451265 & \multicolumn{2}{|c|}{ Akaike info criterion } & 6.406429 \\
\hline Sum squared resid & 475.4607 & \multicolumn{2}{|c|}{ Schwarz criterion } & 6.605575 \\
\hline Log likelihood & -60.06429 & \multicolumn{2}{|c|}{ Durbin-Watson stat } & 2.859006 \\
\hline
\end{tabular}

$$
R O E=C_{1}+C_{2} * C A+C_{3} * N H+C_{4} * I R
$$

As the results show, the P-Value of the coefficients of $\mathrm{C}_{3}$ and $\mathrm{C}_{4}$, which are diversification risk and credit risk, are lower than $5 \%$; so, we can conclude from such data that there is a significant relationship between variables related to interest rate and diversification risk in services and ROE. Also, the amount of $\mathrm{R}^{2}$ is $56 \%$. Durbin Watson statistics are used to show auto-correlation among error tools. As a result, there is no auto-correlation test among error tools.

The value of $\mathrm{F}$ means rejection of $\mathrm{H}_{0}$, meaning that coefficients of the model are zero. As a result, $\mathrm{CR}, \mathrm{NH}$ and IR have significant effects on ROE on significance level of $5 \%$.

Since $\beta$ is positive, NH and IR have a positive correlation with ROE, i.e., ROE increases if NH and IR increase and decreases if $\mathrm{NH}$ and IR decrease. Also, the correlation between $\mathrm{CR}$ and ROE is negative, i.e., ROE decreases if $\mathrm{CR}$ increases and vice versa.

\section{Recommendations for Future Researches}

The objective of this article is to study the effective factors in maximizing stockholders' wealth. According to the findings of this survey, bank managers and decision-makers are recommended to increase their ROE diversification of their services to attract new investors and increase their ROE. In this way, banks' capitals are increased, and it will be possible to offer better and more services again. It can be said that there is a mutual relationship between diversifying services and maximizing banks' capitals. As a result, bank managers can use this issue as an advantage in the competitive market.

Also, we recommend to future researchers to the use of the present model for other financial institutions in the financial market. Moreover, they can recognize risk instruments of banks in the section related to offering electronic services as a subject for dynamic discussion with due attention to the increasing development of such bank services.

\section{References}

Anderson, T.W. (2003). An Introduction to Multivariate Statistical Analysis $\left(3^{\text {rd }}\right.$ edition). Wiley, Hoboken, NJ

Baele, L., Vander Vennet, R., \& van Landschoot, A. (2004). "Bank Risk Strategies and Cyclical Variation in Bank Stock Returns", Working Paper, Faculty of Economics and Business Administration, Ghent University, Ghent

Baele, L., Vander Vennet, R., \& van Landschoot, A. (2007). Does the stock market value bank diversification?. Journal of Banking \& Finance, 31(7), pp. 1999-2023. http://dx.doi.org/10.1016/j.jbankfin.2006.08.003

COSO. (2004). Enterprise Risk Management Integrated Framework. Committee of Sponsoring Organizations of the Treadway Commission.

Das, A. (1999). Profitability of public sector banks: a decomposition model. Reserve Bank of India, Occasional Papers, 20(1), pp. 55-77. 
Das. S. (2006). Risk Management (The Swap and Financial Derivatives Library). Singapore: John Willey \& Sons

Dornbusch, R., Fischer, S., and Startz, R. (2004). The Principle of Macroeconomics (9th edition.). McGraw-Hill. Dubofsky, D.A. (1992). Options and Financial Futures. NY: McGraw-Hill.

Ehrhardt, M.C., \& Brigham E.F. (2011). Corporate Finance: A Focused Approach (4th edition). South-Western.

Fathi, S., \& Bagheri. V. (2008). Designing and Educating Human Management in Iran khodro Co. University of Isfahan.

Greuning, H.V., \& Sonja, B. B. (1999). Analyzing Banking Risk: A Framework for Assessing Corporate Governance and Risk Management (3rd edition). World Bank, Washington DC 1999.

Leea, J.H. (2000). Embedded Options and Interest Rate Risk for Insurance Companies. Banks and Other Financial Institutions. The Quarterly Review of Economics and Finance, 40, 169-187.

Neveu, R.P. (1986). Fundamentals of Managerial Finance (3rd editon). Cincinnati,Ohio: South Western Publish -ing Co.

Ogden J.P., Jen F.C., \& O`connor P.F. (2003). Advanced Corporate Finance: Policies and Strategies. NJ: Prentice Hall.

Raee. R., \& Saeedi. A. (2008). Principles of Financial Engineering and Risk Management. Samt Publishing Co.

Rudra Sensarma. (2009). Are bank stocks sensitive to risk management?. The Journal of Risk Finance, 10(1), 7-22. http://dx.doi.org/10.1108/15265940910924463 